\title{
Genetic Characterization of Flowering Cherries (Prunus subgenus Cerasus) Using rpl16-rpl14 Spacer Sequences of Chloroplast DNA
}

\author{
Satoshi Ohta ${ }^{1,2,3 *}$, Shinsuke Osumi ${ }^{1,2}$, Toshio Katsuki ${ }^{4}$, Ikuo Nakamura $^{5}$, \\ Toshiya Yamamoto ${ }^{3}$ and Yo-Ichiro Sato ${ }^{6}$ \\ ${ }^{1}$ United Graduate School of Agriculture, Gifu University, Yanagido, Gifu 501-1193, Japan \\ ${ }^{2}$ Department of Agriculture, Shizuoka University, Oya, Shizuoka 422-8529, Japan \\ ${ }^{3}$ National Institute of Fruit Tree Science, Fujimoto, Tsukuba 305-8605, Japan \\ ${ }^{4}$ Tama Forest Science Garden, Forestry and Forest Products Research Institute, Todori, Hachioji 193-0843, Japan \\ ${ }^{5}$ Department of Horticulture, Chiba University, Matsudo, Matsudo 271-8510, Japan \\ ${ }^{6}$ Research Institute for Humanity and Nature, Kamigyo, Kyoto 602-0878, Japan
}

\begin{abstract}
Genetic variations among flowering cherries (Prunus subgenus Cerasus) were analyzed by spacer sequences between ribosomal protein L16 (rpll6) and ribosomal protein L14 (rpll4) genes of chloroplast DNA, these sequences were named plastid subtype ID (PS-ID), by using a total of 40 individuals from 11 species and 3 cultivars. Nucleotide sequences of ca. $420 \mathrm{bp}$ were identified as part of $r p l 16$ gene and PS-ID regions. One mutation site was found in partial nucleotide sequences of rpll6 gene. Five different A-repeat types were found at PS-ID region, which were denoted as 9A-T-10A, 10A-T-9A, 13A, 14A, and 15A, respectively. One base change also existed in the downstream of A-repeat. Many individuals (20/22) in species that originated from Japan, except for $P$. pendula f. ascendens, were 14A type, whereas all 9 individuals of $P$. pendula $\mathrm{f}$. ascendens were 10A-T-9A type. Therefore, the maternal line of cultivars related to $P$. pendula f. ascendens can be revealed by the analysis of PS-ID region. In addition, $P$. pendula $\mathrm{f}$. ascendens differs from other Japanese taxa based on morphological traits. The difference is supported from the nucleotide sequences of PS-ID in this study. The A-repeat types of cultivars, i.e., 'Someiyoshino', 'Ichiharatoranoo', and 'Shirotae', were 10A-T-9A type, 14A type, and 14A type, respectively, which suggests that the female parent of the 'Someiyoshino' was $P$. pendula f. ascendens. The results of 'Ichiharatoranoo' and 'Shirotae' analyses were not contradictory to the morphological taxonomy. PS-ID region was highly variable and useful for evaluating genetic variation and elucidating the origin of cultivars.
\end{abstract}

Key Words: Cerasus, chloroplast, flowering cherry, genetic variation, rpl16-rpl14 spacer.

\section{Introduction}

Flowering cherries are classified into Prunus subgenus Cerasus in the family Rosaceae (Koehne, 1913; Rehder, 1940). There are several taxonomic systems in Caresus (Kawasaki, 1991, 2002; Koehne, 1913; Poyarkova, 1941; Rehder, 1940). In most studies, section Microcerasus was classified into subgenus Cerasus. However, species of section Microcerasus differ from section Cerasus on phylogenetic relationships (Bortiri et al., 2002; Lee and Wen, 2001). Therefore, we followed Kawasaki's classification (2002) in treating the section Microcerasus as out of subgenus Cerasus. Species of subgenus Cerasus are mainly distributed among the temperate climate zones on the Northern Hemisphere. Many species of subgenus Cerasus are found in East Asia. Nine species and 4 varieties are in Japan (Kawasaki, 1991), whereas

Received; April 8, 2005. Accepted; July 29, 2005.

Contribution No. 1372 of the National Institute of Fruit Tree Science.

* Corresponding author (E-mail: sohta@affrc.go.jp).
33 species and 6 varieties are distributed in China (Yü and $\mathrm{Li}, 1986$ ). More than 200 flowering cherry cultivars are documented to exist in Japan (Kobayashi, 1992), which have different flower color, form, size, number of petals and so on. Many cultivars are thought to have originated from Japanese native taxa (Kawasaki, 1993; Koidzumi, 1913; Miyoshi, 1916). Some cultivars, such as 'Kanzakura' (Prunus $\times$ kanzakura Makino 'Kanzakura') and 'Kawazuzakura' (P. × kanzakura Makino 'Kawazu-zakura') were bred by cross-pollination with $P$. campanulata endemic to Taiwan. 'Taizanfukun' ( $P . \times$ miyoshii Ohwi 'Ambigua') and 'Myoshoji' ( $P . \times$ introrsa Yagi ex Ohwi 'Myoshoji') were bred by cross-pollination with P. pseudo-cerasus, a native of China (Kawasaki, 1993).

Classification has been made on morphological studies in Prunus subgenus Cerasus (Hayashi, 1980; Kawasaki, 1991; Kobayashi, 1992; Kubota, 1974; Ohba, 1992), and the origin of cultivars based on them (Kawasaki, 1993; Koidzumi, 1913; Miyoshi, 1916). The origin of 'Someiyoshino' ( $P . \times$ yedoensis Matsum. 'Yedoensis'), 
the most familiar caltivar, has often been discussed for its morphological traits (Takenaka, 1963), reference investigation (Funatsu, 1960), restriction analysis of chloroplast DNA (Kaneko et al., 1986), and DNA fingerprinting (Innan et al., 1995), whereas that of many cultivars remains unclear (Kawasaki, 1993). Therefore, our attempt in this study was to clarify the origin of cultivars by the molecular genetic approach. The sequence analysis of chloroplast DNA has been effectively utilized for phylogenic study. Phylogeny of some genera that belong to Rosaceae has been examined similarly (Potter et al., 2002; Shaw and Small, 2004; $\mathrm{Wu}$ et al., 2002). PS-ID is a spacer sequence between ribosomal protein $\mathrm{L} 16$ ( $r p l 16)$ and ribosomal protein $\mathrm{L} 14$ (rpl14) genes of chloroplast DNA. Nakamura et al. (1997) reported that PS-ID region was variable enough to address plastid subtypes of higher plants. Maternal origins were examined by using PS-ID region in Japanese rice populations (Ishikawa et al., 2002).

In this study, we sequenced chloroplast PS-ID region of Prunus subgenus Cerasus in attempt to discriminate Japanese species of Prunus subgenus Cerasus. Three cultivars were used to examine whether the PS-ID region was applicable for the elucidation of their origin.

\section{Materials and Methods}

\section{Plant materials}

Forty individuals that represent 11 species and 3 cultivars in subgenus Cerasus were examined (Table 1). Among them, 9 species are distributed in Japan. The other 2 species, $P$. campanulata and $P$. pseudo-cerasus are endemic to China. 'Someiyoshino', 'Ichiharatoranoo' ( $P$. jamasakura Siebold ex Koidz 'Ichihara') and 'Shirotae' ( $P$. lannesiana (Carrière) E. H. Wilson 'Sirotae') were also studied. Twelve individuals were collected from wild populations, whereas 28 individuals were obtained from botanical gardens. Leaves for DNA extraction from all individuals were frozen or dehydrated immediately after collection, whereas branch specimens were analyzed for morphological characteristics in cooperation with the late Mr. T. Kawasaki. All specimens are kept in the herbarium of Forestry and Forest Products Research Institute, Tama Forest Science Garden (TFA).

\section{DNA extraction}

Total DNA was extracted from frozen $50 \mathrm{mg}$ of leaves by soaking them in ethanol to dehydrate overnight and then pulverizing them by using Multi Beads Shocker (Yasui Kikai, Japan). Samples of dehydrated leaves $(30 \mathrm{mg})$ were crushed into powder in a $1.5 \mathrm{~mL}$ tube. DNA was washed with IB buffer $(10 \%$ polyethyleneglycol, $0.35 \mathrm{M}$ sorbitol, 0.1 M Tris-HCl, pH 7.5-8.0, 1\% 2-mercaptoethanol) and LB buffer $(0.35 \mathrm{M}$ sorbitol, $0.1 \mathrm{M}$ Tris- $\mathrm{HCl}, \mathrm{pH}$ 7.5-8.0, 1\% 2-mercaptoethanol). Then, $800 \mu \mathrm{L}$ of DNA extraction buffer (Lefort and Douglas, 1999) was added to the washed sample and incubated for $15 \mathrm{~min}$ at $65^{\circ} \mathrm{C}$. Four hundred $\mu \mathrm{L}$ of chloroform/isoamylalcohol $(24: 1, \mathrm{v} / \mathrm{v})$ was added to the mixture and centrifuged $\left(10000 \mathrm{rpm}, 5 \mathrm{~min}, 4^{\circ} \mathrm{C}\right)$ to isolate DNA solution. Upon removing the residue, $700 \mu \mathrm{L}$ of isopropanol was added and the supernatant was centrifuged $\left(15000 \mathrm{rpm}, 5 \mathrm{~min}, 4^{\circ} \mathrm{C}\right)$ to obtain DNA pellet. The pellet was dissolved in TE $(10 \mathrm{mM}$ Tris- $\mathrm{HCl}$, $\mathrm{pH} 7.5-8.0,2 \mathrm{mM}$ EDTA) to which $300 \mu \mathrm{L}$ of phenol/ chloroform (1:1) was added and centrifuged $(15000 \mathrm{rpm}$, $10 \mathrm{~min}, 4^{\circ} \mathrm{C}$ ) to remove proteins. On adding $900 \mu \mathrm{L}$ of ethanol and $30 \mu \mathrm{L}$ of $3 \mathrm{M}$ sodium acetate, the solution was centrifuged $\left(15000 \mathrm{rpm}, 10 \mathrm{~min}, 4^{\circ} \mathrm{C}\right)$ to precipitate DNA that was washed with $70 \%$ ethanol. Subsequently, the DNA solution was eluted through a Sephadex column (G-50 DNA Grade M, Amersham, USA) at $4^{\circ} \mathrm{C}$.

\section{Sequencing of PS-ID regions}

PS-ID is a link region between rpll6 and rpll4 (Fig. 1). The A primer (5'-AAAGATCTAGATTTCGTAAACAACATAGAGGAAGAA-3') and B primer (5'ATCTGCAGCATTTAAAAGGGTCTGAGGTTGAATCAT-3') were used for PCR amplification. The A primer was used to amplify not only PS-ID region but also part of rpll6 gene.

PCR amplification was performed in a $25 \mu \mathrm{L}$ solution of $10 \mathrm{mM}$ Tris- $\mathrm{HCl}(\mathrm{pH} 8.3), 50 \mathrm{mM} \mathrm{KCl}, 1.5 \mathrm{mM}$ $\mathrm{MgCl}_{2}, 0.01 \%$ gelatin, $0.2 \mathrm{mM}$ each of dNTPs, $10 \mathrm{pM}$ of each primer, $10 \mathrm{ng}$ of genomic DNA, and 0.5 unit of Taq polymerase (TaKaRa, Japan). The PCR profile consisted of an initial denaturation for $4 \mathrm{~min}$ at $94^{\circ} \mathrm{C}$ followed by 33 cycles of $1 \mathrm{~min}$ at $94^{\circ} \mathrm{C}, 1 \mathrm{~min}$ at $52^{\circ} \mathrm{C}$, $1 \mathrm{~min}$ at $72^{\circ} \mathrm{C}$, and a final extension of $4 \mathrm{~min}$ at $72^{\circ} \mathrm{C}$.

The PCR products were purified and then cycle sequence reaction was performed by using BigDye Terminator Cycle Sequence Kit (Applied Biosystems, USA) with A primer or A3 primer (5'-GGTAGCCGTTGTTAAACCAGGTCGAATACTTTATG-3') and B primer. Sequencing was performed by using a PRISM 3100 Genetic Analyzer (Applied Biosystems, USA). Sequences of all individuals were compared by using DNASIS ver. 3.7 (Hitachi Software, Japan).

\section{Results and Discussion}

\section{Variation at rpl16 and PS-ID regions}

Nucleotide sequences of ca. $420 \mathrm{bp}$ were identified as part of rpll6 gene and PS-ID regions from species of Prunus subgenus Cerasus (Fig. 2). Nucleotide sequences of 1st to 331st position (denoted by capital letters in Fig. 2) were part of $r p l 16$ gene and the downstream region from 332nd nucleotide (denoted by small letters in Fig. 2) were part of the PS-ID region.

One mutation site $(\mathrm{C} / \mathrm{T}, 19$ th nucleotide) was found in 2 individuals of $P$. maximowiczii (Cherry-Ohta 158 and Cherry-Ohta 076) at partial nucleotide sequences of rpll6 gene (Table 1, Fig. 2). Five different sequences, i.e., A9TA10, A10TA9, A13, A14, and A15 were found in PS-ID regions (Table 2). These were denoted as 9AT-10A, 10A-T-9A, 13A, 14A and 15A, respectively. The 


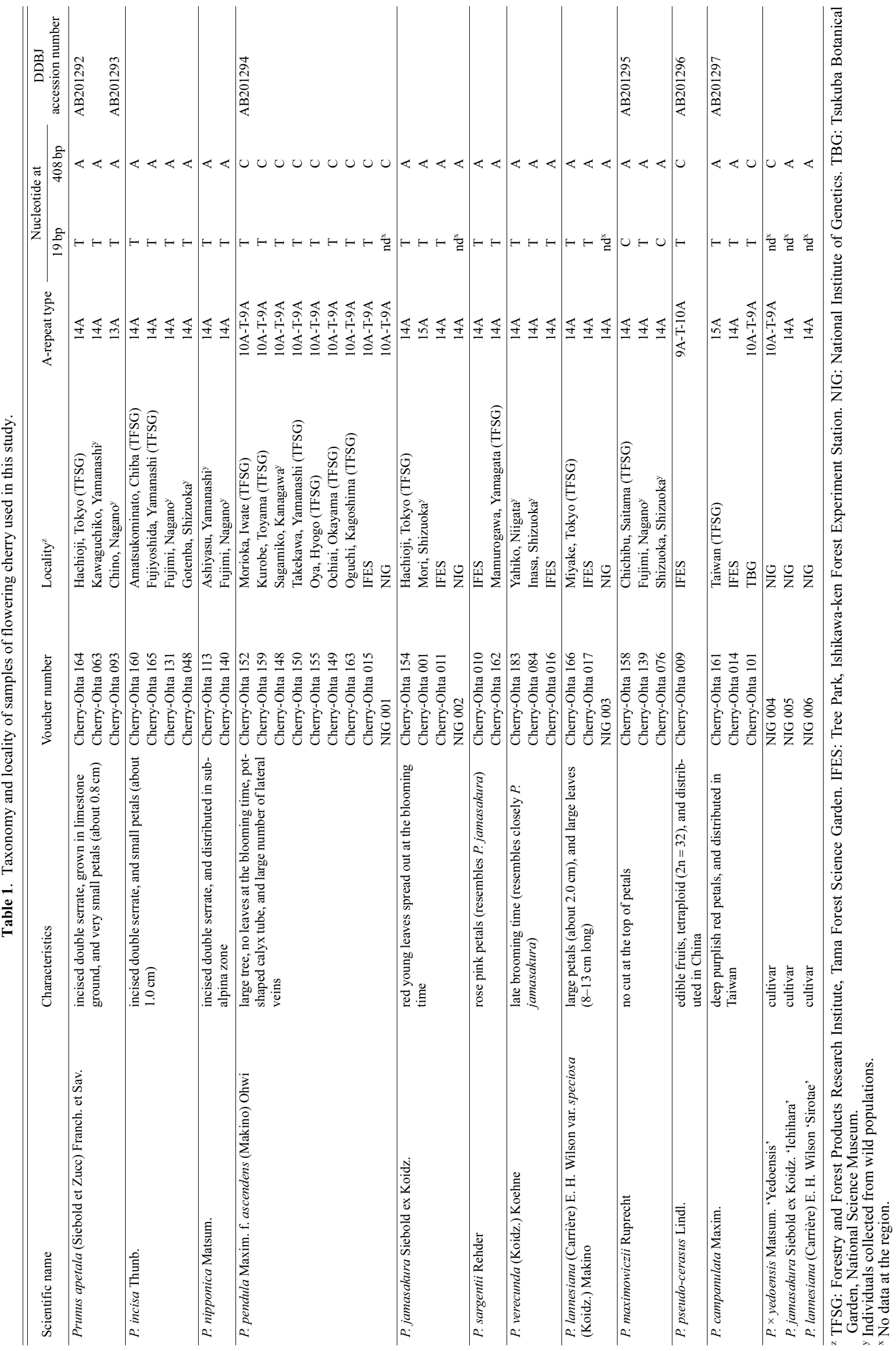




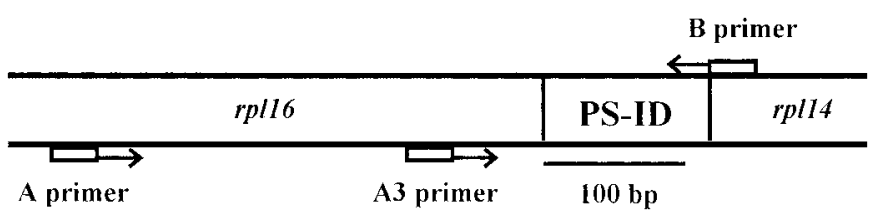

Fig. 1. Primer sites for amplifying the PS-ID (Plastid subtype ID) region located in an intergenic region between rpl16 (ribosomal protein L16) and rpl14 (ribosomal protein L14).

\begin{tabular}{|c|c|c|c|c|c|}
\hline & 1 & 11 & 21 & 31 & 41 \\
\hline Cherry-Ohta 158 & TATTTGCTTC & GGTAGATACG & СТСTTCAAGC & GCTTGAACCC & GCTTGGATCA \\
\hline Cherry-Ohta 161 & TATTTGCTTC & GGTAGATATG & СТСТTСAAGC & GCTTGAACCC & GCTTGGATCA \\
\hline \multirow[t]{2}{*}{ Cherry-Ohta 152} & TATTTGCTTC & GGTAGATATG & СТСТTCAAGC & GCTTGAACCC & GCTTGGATCA \\
\hline & 51 & 61 & 71 & 81 & 91 \\
\hline Cherry-Ohta 158 & САTCTAGACA & AATAGAAGCA & GGGCGGCGAG & CAATGACACG & AAACGCACGC \\
\hline Cherry-Ohta 161 & CATCTAGACA & AATAGAAGCA & GGGCGGCGAG & CAATGACACG & AAACGCACGC \\
\hline \multirow[t]{2}{*}{ Cherry-Ohta 152} & CATCTAGACA & AATAGAAGCA & GGGCGGCGAG & CAATGACACG & AAACGCACGC \\
\hline & 101 & 111 & 121 & 131 & 141 \\
\hline Cherry-Ohta 158 & CGCGGTGGAA & AAATATGGGT & ACGCATATTT & CCAGACAAAC & CCGTTACAGT \\
\hline Cherry-Ohta 161 & CGCGGTGGAA & AAATATGGGT & АCGCATATTT & CCAGACAAAC & CCGTTACAGT \\
\hline \multirow[t]{2}{*}{ Cherry-Ohta 152} & CGCGGTGGAA & AAATATGGGT & АCGCATATTT & CCAGACAAAC & CCGTTACAGT \\
\hline & 151 & 161 & 171 & 181 & 191 \\
\hline Cherry-Ohta 158 & AAGACCTACA & GAAACACGTA & TGGGTTCGGG & TAAAGGATCT & CCCGAАTATT \\
\hline Cherry-Ohta 161 & AAGACCTACA & GAAACACGTA & TGGGTTCGGG & TAAAGGATCT & CССGААТАTT \\
\hline \multirow[t]{2}{*}{ Cherry-Ohta 152} & AAGACCTACA & GAAACACGTA & TGGGTTCGGG & TAAAGGATCT & СССGAАTАТT \\
\hline & 201 & 211 & 221 & 231 & 241 \\
\hline Cherry-Ohta 158 & GGGTAGCTGT & TGTTAAACCC & GGTAGAATAC & TTTATGAAAT & GAGCGGAGTA \\
\hline Cherry-Ohta 161 & GGGTAGCTGT & TGTTAAACCC & GGTAGAATAC & TTTATGAAAT & GAGCGGAGTA \\
\hline \multirow[t]{2}{*}{ Cherry-Ohta 152} & GGGTAGCTGT & TGTTAAACCC & GGTAGAATAC & TTTATGAAAT & GAGCGGAGTA \\
\hline & 251 & 261 & 271 & 281 & 291 \\
\hline Cherry-Ohta 158 & GCAGAAAATA & TAGCCAGAAG & GGCAATTTCA & ATAGCGGCAT & CCAAAATGCC \\
\hline Cherry-Ohta 161 & GCAGAAAATA & TAGCCAGAAG & GGCAATTTCA & ATAGCGGCAT & CCAAAATGCC \\
\hline \multirow[t]{2}{*}{ Cherry-Ohta 152} & GCAGAAAATA & TAGCCAGAAG & GGCAATTTCA & ATAGCGGCAT & CCAAAATGCC \\
\hline & 301 & 311 & 321 & 331 & 341 \\
\hline Cherry-Ohta 158 & TATACGAACT & СААТTСАТТС & TTTCGGGATA & Gggatgtaga & aacaaaggaa \\
\hline Cherry-Ohta 161 & TATACGAACT & СААТTСАТТС & TTTCGGGATA & Gggatgtaga & aacaaaggaa \\
\hline \multirow[t]{2}{*}{ Cherry-Ohta 152} & TATACGAACT & СААТTСАТТС & TTTCGGGATA & Gggatgtaga & aacaaaggaa \\
\hline & 351 & 361 & 371 & 381 & 391 \\
\hline Cherry-Ohta 158 & aggggtcttt & tgtatgaaaa & aaaaaaaa & $-----\operatorname{ttg} c$ & aggttttttg \\
\hline Cherry-Ohta 161 & aggggtcttt & tgtatgaaaa & aaaaaaaaa & $a-----\operatorname{ttg} c$ & aggttttttg \\
\hline \multirow[t]{2}{*}{ Cherry-Ohta 152} & aggggtcttt & tgtatgaaaa & aaaaataaa & aaaaattgc & aggttttttg \\
\hline & 401 & 411 & & & \\
\hline Cherry-Ohta 158 & ttttgaaaaa & ataatattt & & & \\
\hline Cherry-Ohta 161 & ttttgaaaaa & ataatattt & & & \\
\hline Cherry-Ohta 152 & ttttgaaça & ataatattt & & & \\
\hline
\end{tabular}

Fig. 2. Nucleotide sequences of rpll6 (ribosomal protein L16) and PS-ID (Plastid subtype ID) regions in 3 individuals of Prunus subgenus Cerasus. Individuals of Cherry-Ohta 158, Cherry-Ohta 161 and Cherry-Ohta 152, are classified as P. maximowiczii, P. campanulata and P. pendula f. ascendens, respectively. Nucleotide sequences of the rpl16 and PS-ID regions are shown in capital and small letters, respectively. Substitution sites and A repeat regions are shown in boxes and underline, respectively.

most frequent type was $14 \mathrm{~A}$ in which 23 individuals of wild species were involved. It was observed in all wild species except for $P$. pendula f. ascendens and $P$. pseudocerasus. The 9A-T-10A type, 10A-T-9A type, 13A type, and $15 \mathrm{~A}$ type were occurred $1,10,1$, and 2 individuals, respectively. The 10A-T-9A type was found in 10 individuals of wild species, of which 9 were in $P$. pendula f. ascendens. As for the PS-ID region, 1 base change (C/A, 408th nucleotide) existed in the downstream of A-repeat, which corresponded to the sequences of 9AT-10A type and 10A-T-9A type (Table 1). Five haplotypes were distinguished from the sequence of PSID region (81-88 bp long). Only one site of base change existed in part of rpll 6 gene (331 bp long). These results 
Table 2. Five A-repeat types in PS-ID observed in subgenus Cerasus.

\begin{tabular}{ll}
\hline \hline Type & Sequence \\
\hline 9A-T-10A & AAAAAAAAATAAAAAAAAAA \\
$10 \mathrm{~A}-\mathrm{T}-9 \mathrm{~A}$ & AAAAAAAAAATAAAAAAAAA \\
$13 \mathrm{~A}$ & AAAAAAAAAAAAA \\
$14 \mathrm{~A}$ & AAAAAAAAAAAAAA \\
$15 \mathrm{~A}$ & AAAAAAAAAAAAAAA
\end{tabular}

indicated that PS-ID region is highly variable.

Variation of intra- and inter-species

An intraspecific variation of part of rpl16 gene (19th $\mathrm{C} / \mathrm{T}$ ) was observed only in $P$. maximowiczii (Table 1 ). Two individuals of $P$. maximowiczii (Cherry-Ohta 158 and Cherry-Ohta 076) contained a $\mathrm{C}$ nucleotide at the mutation site (Table 1, Fig. 2). The other one showed a $\mathrm{T}$ nucleotide. $P$. maximowiczii is morphologically different from other Japanese species, based on phenotypic traits, such as having no cut at the tip of petals, raceme, and remaining large bract. Therefore, it was thought that two individuals of $P$. maximowiczii have a different genetic background. An intraspecific variation of A-repeat type at PS-ID was seen in 3 species, i.e., $P$. apetala, $P$. jamasakura and $P$. campanulata (Table 3). Out of 3 individuals of $P$. apetala, CherryOhta 093 was a 13A type, while Cherry-Ohta 164 and Cherry-Ohta 063 were of the 14A type. Among 4 individuals of P. jamasakura, Cherry-Ohta 001 was a 15A type, while Cherry-Ohta 154, Cherry-Ohta 011 , and NIG 002 were in the $14 \mathrm{~A}$ type. All 3 individuals of $P$. campanulata showed different A-repeat types. CherryOhta 101, Cherry-Ohta 014, and Cherry-Ohta 161 were identified as types, 10A-T-9A, 14A, and 15A, respectively. There were no intra-specific variations in other wild species used in this study except for P. pseudocerasus. All 9 individuals of $P$. pendula f. ascendens were 10A-T-9A type, and one individual of P. pseudo- cerasus (Cherry-Ohta 009) was 9A-T-10A type. In addition, the individuals with $14 \mathrm{~A}$ were $4 P$. incisa, 2 $P$. nipponica, $2 P$. sargentil, $3 P$. verecunda, $3 P$. lannesiana var. speciosa, and 3 P. maximowiczii.

All 9 individuals of $P$. pendula $\mathrm{f}$. ascendens, that were 10A-T-9A type, had a base change of A to $\mathrm{C}$ at 408th nucleotide (Table 1). Only one individual of wild species (Cherry-Ohta 101; P. campanulata) was the same haplotype as $P$. pendula f. ascendens. These results suggest that the maternal line of cultivars, related to $P$. pendula f. ascendens, will be revealed by the analysis of their PS-ID regions. Hence, when a cultivar, related to $P$. pendula $\mathrm{f}$. ascendens, was 10A-T-9A type, its maternal parent would be $P$. pendula f. ascendens. There are many morphological differences between $P$. pendula f. ascendens and $P$. campanulata such as the existence of hair on leaves and petioles, the number of lateral veins in the leaf blades, the shape of calyx tube, and petal color (Kawasaki, 1993). Therefore, cultivars of the 10AT-9A type of A-repeat can be distinguished as being derivatives of $P$. pendula f. ascendens or P. campanulata as their maternal parentage. Thus, a cultivar, related to P. pendula f. ascendens, that was not 10A-T-9A type, $P$. pendula f. ascendens would be its male parent. Kaneko et al. (1986) distinguished P. pendula f. ascendens from some Japanese native taxa of subgenus Cerasus based on restriction endonuclease analysis of chloroplast DNA, but their study did not include $P$. jamasakura, $P$. incisa, $P$. campanulata and so on. Furthermore, the difference between $P$. pendula f. ascendens and some Japanese native taxa was only one restriction site. In this study, $P$. pendula f. ascendens was distinguished from Japanese native taxa of subgenus Cerasus, including all taxa except for local varieties, based on A-repeat type and 1 site of base change at PS-ID region. Intraspecific variations were also observed in some species classified into different sections such as, $P$. apetala, $P$.jamasakura, and $P$. campanulata (Table 3 ). Especially, 3 individuals from $P$. campanulata, species from a foreign country,

Table 3. Variation of repeat types observed in PS-ID in each taxon of subgenus Cerasus.

\begin{tabular}{|c|c|c|c|c|c|}
\hline \multirow{2}{*}{ Taxon } & \multicolumn{5}{|c|}{ A-repeat type ${ }^{z}$} \\
\hline & $9 \mathrm{~A}-\mathrm{T}-10 \mathrm{~A}$ & $10 \mathrm{~A}-\mathrm{T}-9 \mathrm{~A}$ & $13 \mathrm{~A}$ & $14 \mathrm{~A}$ & $15 \mathrm{~A}$ \\
\hline P. apetala & 0 & 0 & 1 & 2 & 0 \\
\hline P. incisa & 0 & 0 & 0 & 4 & 0 \\
\hline P. nipponica & 0 & 0 & 0 & 2 & 0 \\
\hline P. pendula f. ascendens & 0 & 9 & 0 & 0 & 0 \\
\hline P. jamasakura & 0 & 0 & 0 & 3 & 1 \\
\hline P. sargentii & 0 & 0 & 0 & 2 & 0 \\
\hline P. verecunda & 0 & 0 & 0 & 3 & 0 \\
\hline P. lannesiana var. speciosa & 0 & 0 & 0 & 3 & 0 \\
\hline P. maximowiczii & 0 & 0 & 0 & 3 & 0 \\
\hline P. campanulata & 0 & 1 & 0 & 1 & 1 \\
\hline P. pseudo-cerasus & 1 & 0 & 0 & 0 & 0 \\
\hline
\end{tabular}

${ }^{\mathrm{z}}$ Number of individuals showing each repeat type is indicated. 
had different A-repeat sequences. Therefore, it was thought that adding the analysis of PS-ID region was much better than the analysis only by restriction endonuclease to formulate the relationships among subgenus Cerasus.

\section{Relationships among Prunus subgenus Cerasus}

$P$. pendula f. ascendens showed a different haplotype from other Japanese species. It differs from other Japanese taxa based on morphological traits, such as its pot-shaped calyx tube, elliptical shape of leaves, and large number of lateral veins in the leaf blades. Thus, $P$. pendula f. ascendens is commonly considered to be genetically far apart from other Japanese taxa (Kawasaki, 1991; Kobayashi, 1992); this is also supported from the nucleotide sequence of PS-ID in this study. However, it will be necessary to investigate more regions to establish exact relationships among subgenus Cerasus.

Three individuals from $P$. campanulata and 1 individual from $P$. pseudo-cerasus, that are the species from a foreign country, were different A-repeat types, whereas 20 individuals among 22 individuals in wild species that originated in Japan, except for $P$. pendula f. ascendens, were the 14A type. These results suggested that Japanese species have a smaller variation than do the foreign species. Our results indicate that some haplotypes existed in Japanese and foreign species, and that the analysis of PS-ID region is useful to elucidate the origin of the Japanese flowering cherry (Prunus subgenus Cerasus). It is interesting that the same base change occurred in the downstream of 2 types of Arepeat (the 9A-T-10A and the 10A-T-9A) when discussing the relation among haplotypes.

\section{Analysis of cultivars}

The A-repeat types of 'Someiyoshino', 'Ichiharatoranoo', and 'Shirotae' were 10A-T-9A type, 14A type and 14A type, respectively (Table 1). 'Someiyoshino' showed the same haplotype as $P$. pendula f. ascendens, characterized by 10A-T-9A type and the base change at the 408th nucleotide (Table 1). Hence, it is considered a hybrid between $P$. pendula $\mathrm{f}$. ascendens and $P$. lannesiana var. speciosa based on morphological traits, crossing experiment, and reference investigation (Funatsu, 1960; Takenaka, 1963). It was suggested that the female parent of the 'Someiyoshino' is $P$. pendula f. ascendens, because they have the same haplotype at PS-ID region. This is in agreement with restriction endonuclease analysis of chloroplast DNA by Kaneko et al. (1986). However, our result is contradictory in that 'Someiyoshino' is an offspring of $P$. lannesiana var. speciosa as a female plant (Funatsu 1960). The question whether 'Someiyoshino' reported by Funatsu (1960) is identical to that used in this study remains further study. 'Ichiharatoranoo' and 'Shirotae' are thought to have originated from $P$. jamasakura and $P$. lannesiana var. speciosa, respectively (Kawasaki, 1993) as they are 14A types at PS-ID region. These results are not contradictory to the in morphological taxonomy.

Since many cultivars are related to $P$. pendula $\mathrm{f}$. ascendens, such as 'Kohigan' $(P . \times$ subhirtella Miq. 'Subhirtella'), 'Koshinohiganzakura' ( $P$. koshiensis Koidz.) and 'Kabazakura' ( $P . \times$ media Miyoshi 'Media'), the analysis of the PS-ID region seems applicable for the elucidation of the origin of the flowering cherries.

\section{Acknowledgements}

The authors are grateful to the late Mr. T. Kawasaki for his co-operation on taxonomy of flowering cherries used in this study. We thank to Mr. Y. Sengi and Dr. H. Hatta for providing flowering cherry germplasms.

\section{Literature Cited}

Bortiri, E., S. H. Oh, F. Y. Gao and D. Potter. 2002. The phylogenetic utility of nucleotide sequences of sorbitol 6-phosphate dehydrogenase in Prunus (Rosaceae). Amer. J. Bot. 89: 1697-1708.

Funatsu, K. 1960. Who raised Prunus yedoensis Matsum. Collecting and Breeding 28: 95 (In Japanese).

Hayashi, Y. 1980. One hundred of selective flowering cherries (In Japanese). New Science, Tokyo.

Ishikawa, R., Y.-I. Sato, T. Tang and I. Nakamura. 2002. Different maternal origins of Japanese lowland and upland rice populations. Theor. Appl. Genet. 104: 976-980.

Innan, H., R. Terauchi, N. T. Miyashita and K. Tsunewaki. 1995. DNA fingerprinting study on the intraspecific variation and the origin of Prunus yedoensis (Someiyoshino). Jpn. J. Genet. 70: 185-196.

Kaneko, T., T. Terachi and K. Tsunekawa. 1986. Studies on the origin of crop species by restriction endonuclease analysis of organellar DNA. II. Restriction analysis of ctDNA of 11 Prunus species. Jpn. J. Genet. 61: 157-168.

Kawasaki, T. 1991. The distribution of Prunus subgenus Cerasus in East-Asia and classification of Japanese wild species. Sakura Science 1: 28-45 (In Japanese with English summary).

Kawasaki, T. 1993. Flowering cherries of Japan (In Japanese). Yama-kei Publishers, Tokyo.

Kawasaki, T. 2002. The classification of Prunus subgenus Cerasus. Forestry Technology 719: 22-25 (In Japanese).

Kobayashi, Y. 1992. Flowering cherry cultivars. Planter 20: 9-14 (In Japanese).

Koidzumi, G. 1913. Conspectus Rosacearum Japonicarum. J. Coll. Sci. Imp. Univ. Tokyo 34: 254-286 (In German).

Koehne, E. 1913. Prunus L. subgen. Cerasus. p. 226-262. In: C. S. Sargent (ed.). Plantae Wilsonianae vol. 1. Harvard University Press, Massachusetts.

Kubota, H. 1974. Wild flowering cherries. p. 64-99 (In Japanese). In: S. Honda and S. Hayashi (eds.). Flowering cherries of Japan. Seibundo Shinkosya, Tokyo.

Lee, S. and J. Wen 2001. A phylogenetic analysis of Prunus and the Amygdaloideae (Rosaceae) using ITS sequences of nuclear ribosomal DNA. Amer. J. Bot. 88: 150-160.

Lefort, F. and G. C. Douglas 1999. An efficient micro-method 
of DNA isolation from mature leaves of four hardwood tree species Acer, Fraxinus, Prunus and Quercus. Ann. For. Sci. 56: 259-263.

Miyoshi, M. 1916. Japanische Bergkirschen, ihre Wildformen und Kulturrassen. J. Coll. Sci. Imp. Univ. Tokyo 34: 175 (In German).

Nakamura, I., N. Kameya, Y. Kato, S. Yamanaka, H. Jomori and Y. Sato. 1997. A proposal for identifying the short ID sequence which addresses the plastid subtype of higher plants. Breed. Sci. 47: 385-388.

Ohba, H. 1992. Japanese cherry trees under the genus Cerasus (Rosaceae). J. Jpn. Bot. 67: 276-281.

Potter, D., F. Gao, P. E. Bortiri, S. H. Oh and S. Baggett. 2002. Phylogenetic relationships in Rosaceae inferred from chloroplast matK and trnL-trnF nucleotide sequence data. Plant Syst. Evol. 231: 77-89.

Poyarkova, A. I. 1941. Genus Cerasus. p. 547-575 (In
Russian). In: V. L. Komarov (ed.). Flora SSSR vol 10, Akad. Nauk. SSSR, Moskva Leningrad.

Rehder, A. 1940. Manual of cultivated trees and shrubs, 2nd edn. Macmillan, New York.

Shaw, J. and R. Small. 2004. Addressing the "hardest puzzle in American pomology:" Phylogeny of Prunus sect. Prunocerasus (Rosaceae) based on seven noncoding chloroplast DNA regions. Amer. J. Bot. 91: 985-996.

Takenaka, Y. 1963. The origin of the Yoshino cherry tree. J. Hered. 54: 207-211.

Wu, S., Y. Ueda, H. He, S. Nishihara and S. Matsumoto. 2002. Phylogenetic analysis of Japanese Rosa species using matK sequences. Breed. Sci. 50: 275-281.

Yü, T. T. and C. L. Li. 1986. Cerasus. p. 1-133 (In Chinese). In: T. T. Yü (ed.). Flora Reipublicae Popularis Sinicae 38, Science Press, Beijing.

葉緑体 rpl16-rpl14 領域の塩基配列によるサクラ属サクラ亜属の遺伝的特徵づけ

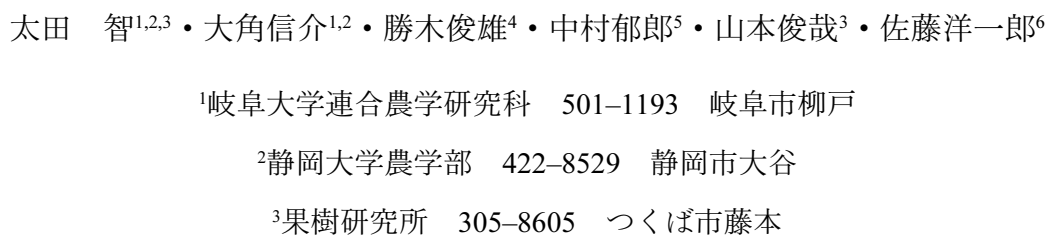

4森林総合研究所多摩森林科学園 193-0843 八王子市廿里町

5 千葉大学園芸学部 271-8510 松戸市松戸

6総合地球環境学研究所 602-0878 京都市上京区

サクラ属サクラ亜属 11 種掞よび 3 つの栽培品種から 合計 40 個体を用い, 葉緑体 rpll6-rpl14 (PS-ID) 領域の 塩基配列により遺伝的変異を明らかにした. rpll6 遺伝子 の一部拉よび PS-ID 領域の合計約 420 塩基対の配列が決 定できた. rpll6 遺伝子の一部には, 1 か所の塩基置換が 存在した. PS-ID 領域には 5 種類の A リピートが認めら れ，それぞれ 9A-T-10A，10A-T-9A，13A，14A 打よび $15 \mathrm{~A}$ と名付けた. A リピートの下流には, 1 か所の塩基置 換が存在した. エドヒガンは 9 個体すべてが 10A-T-9A 型であった，一方，エドヒガンを除く日本産の種では, 多くの個体（20/22）が 14A 型だった。したがって, PSID 領域の分析により, エドヒガンに由来する栽培品種の
母系が明らかにできると考兄られた，さらに，エドヒガ ンは形態的に他の日本産の分類群とは異なるが，このこ とは今回の PS-ID 領域の塩基配列からも支持された. 3 つの栽培品種, “染井吉野”, “市原虎の尾”拈よび ‘白 妙のA リピート型は，そ秃ぞれ 10A-T-9A 型，14A 型 および 14A 型であった。このことから “染井吉野” の母 親はエドヒガンであることが示唆された。“市原虎の尾” 牧よび ‘白妙”の結果も, 形態学的な分類と矛盾がなかっ た. これらの結果から PS-ID 領域は, 日本産のサクラ亜 属の由来や, 栽培品種の由来を解明するのに有効と考兄 られた。 